\title{
APPLICATION OF A 2-D NUMERICAL MODEL FOR COMPUTING SUSPENDED SEDIMENT AND NUTRIENTS TRANSPORTS TO NHUE RIVER (HANOI, VIETNAM)
}

\author{
Anh Duc TRINH ${ }^{1}$, Yoshihisa AKAMATSU², Syunsuke IKEDA ${ }^{3}$, Lan Anh LE ${ }^{1}$, Duc Loi VU ${ }^{1}$ \\ ${ }^{1}$ Analytical Laboratory, Institute of Chemistry, V.A.S.T. (18 Hoang Quoc Viet, Cau Giay, Hanoi, Vietnam) \\ ${ }^{2}$ Department of Environmental Science and Technology, Graduate School of Science and Engineering, Tokyo Institute of Technology \\ (4259-G5-3 Nagatuda, Midori-ku, Yokohama 226-8502, Japan) \\ ${ }^{3}$ Department of Civil Engineering, Graduate School of Science and Engineering, Tokyo Institute of Technology (2-12-1-M1-1, \\ Ookayama, Meguro-ku, Tokyo 152-8552, Japan)
}

\begin{abstract}
Since suspended sediment and organic matter loads were extremely high in Nhue River (Hanoi, Vietnam), a 2-D depth-average model was constructed to simulate hydrodynamic state, suspended sediment transport and environmental change around the confluence between Nhue River and its tributary, To Lich River. The biochemical conversions were constructed based on the QUAL2E conceptual scheme ${ }^{1)}$. The model is capable of backwater simulation that was frequently seen there. The simulation results indicated a strong suspended sediment deposition. A clear deterioration of environment was simulated. Within few hundred meters from the confluence two water masses were incompletely mixed in normal discharge condition.
\end{abstract}

Key words: Nhue River, Hanoi, 2-D model, QUAL2E, suspended sediment, wastewater pollution

\section{INTRODUCTION}

Fast urbanization and rapid economics development in Vietnam without efficient collect and treatment of wastewaters lead to a dramatic degradation of environment. In Hanoi capital city of Vietnam, the wastewater is not directly discharged to the Red River, but largely flows through Nhue River, a tributary of the Red River (Fig. 1). With a population of more than 3 millions and no wastewater treatment facility ${ }^{2)}$, the city's wastewater characterized by extremely high BOD and containing fully suspended organic particulate provokes a severe problem to the environment of Nhue River from the confluence of the city main sewer line, To Lich River. Based on the fact that suspended loads in both rivers, Nhue and To Lich, are high, in this work, we applied a 2-D numerical model for studying the hydrodynamic state, suspended sediment (SS) transport and nutrients changes around the confluence between two rivers.

\section{DESCRIPTION OF THE STUDIED SITE}

The calculation area is junction of Nhue and To Lich Rivers which consists of about $1600 \mathrm{~m}$ of Nhue River and nearly 800 m of To Lich River (Fig. 1). Briefly, To Lich River stems from the West Lake located in the northern part of Hanoi, flows across the city to the south before joining Nhue River in a

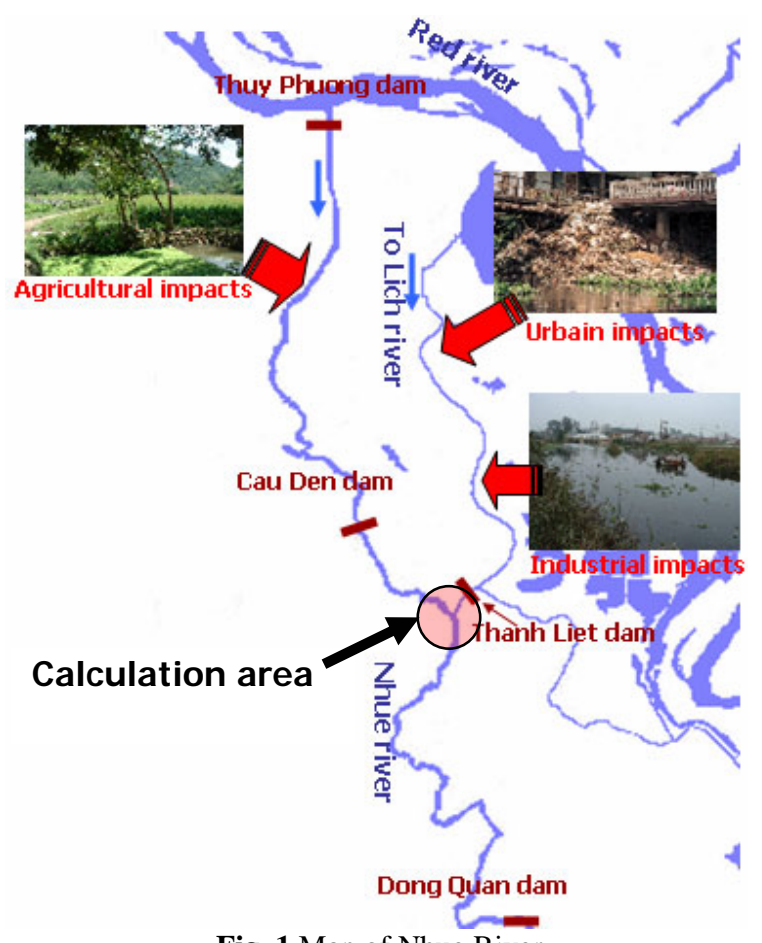

Fig. 1 Map of Nhue River

total of $14 \mathrm{~km}$ length. The wastewaters of the city were directly discharged into To Lich River without any treatment and turned this river into a main openair sewer of the city. The Nhue River takes its source from the Red River in the north west of Hanoi city, collects the To Lich's water at $20.2 \mathrm{~km}$, and joins the Chau Giang River at $72 \mathrm{~km}$ (not in the map). The mean water depths in normal discharge of 
the Nhue and To Lich Rivers are about 2.5 and 1.5 $\mathrm{m}$, respectively.

The Nhue River's water was characterized by high SS content because its water source stems from the Red River where water was famous of high SS load $^{3)}$. Our monthly surveys during the years 2002 and 2003 gave an average $265 \mathrm{mg} / \mathrm{l}$ of SS. Particularly, during rainy season the Red River water usually contained more than $1000 \mathrm{mg}$ SS/l (Fig. 2). Different from the Red River water where inorganic solid accounted for large proportion of SS, SS in To Lich water was characterized mostly by organic detritus. The surveys during 2002-2003 have shown average $75 \mathrm{mg} \mathrm{SS} / \mathrm{l}$ in To Lich River. In dry time, when only domestic wastewater presented in the river, the SS content could increase up to 160 mg SS/l. The BOD value showed clearly the pollution condition of To Lich River where monthly BOD in dry time reached as high as $70 \mathrm{mg} \mathrm{O}_{2} / \mathrm{l}$ (Fig. 3). The high loads of SS and BOD of two main water sources resulted in water pollution and many other severe problems to aquatic species as well as local inhabitants ${ }^{2}$.

\section{MODEL SETUP}

The biochemical conversion module was set up based on the conceptual scheme of the Enhanced Stream Water Quality Model (QUAL2E or Q2E) constructed by $\mathrm{EPA}^{4}$ ). The biological conversion of environmental variables integrated with the transport equations of 2-D depth average concentration of material provides insight of the environmental variation of the studied river section.

The considered state variables extracted from QUAL2E conceptual scheme ${ }^{1)}$ are listed in Table 1. This selected variable set gives advantage in modeling $\mathrm{pH}$, an essential parameter governing the partition of various species in aquatic environment.

Bottom attaching algae were not considered in this conceptual scheme since water in this studied system was turbid and irradiation was completely attenuated before reaching to the river bottom.

Governing equations for surface flow are

$$
\begin{aligned}
& \frac{\partial h}{\partial t}+\frac{\partial(u h)}{\partial x}+\frac{\partial(v h)}{\partial y}=0 \text { (1) } \\
& \frac{\partial(u h)}{\partial t}+\frac{\partial\left(u^{2} h\right)}{\partial x}+\frac{\partial(u v h)}{\partial y}=-g h \frac{\partial z_{s}}{\partial x}-\frac{\tau_{b}^{x}}{\rho}-\frac{\tau_{v}^{x}}{\rho} \\
& +\frac{\partial}{\partial x}\left(-\overline{u^{\prime 2}} h\right)+\frac{\partial}{\partial y}\left(-\overline{u^{\prime} v^{\prime}} h\right) \\
& \frac{\partial(u h)}{\partial t}+\frac{\partial(u v h)}{\partial x}+\frac{\partial\left(v^{2} h\right)}{\partial y}=-g h \frac{\partial z_{s}}{\partial y}-\frac{\tau_{b}^{y}}{\rho}-\frac{\tau_{v}^{y}}{\rho} \\
& +\frac{\partial}{\partial x}\left(-\overline{u^{\prime} v^{\prime}} h\right)+\frac{\partial}{\partial y}\left(-\overline{v^{\prime 2}} h\right)
\end{aligned}
$$

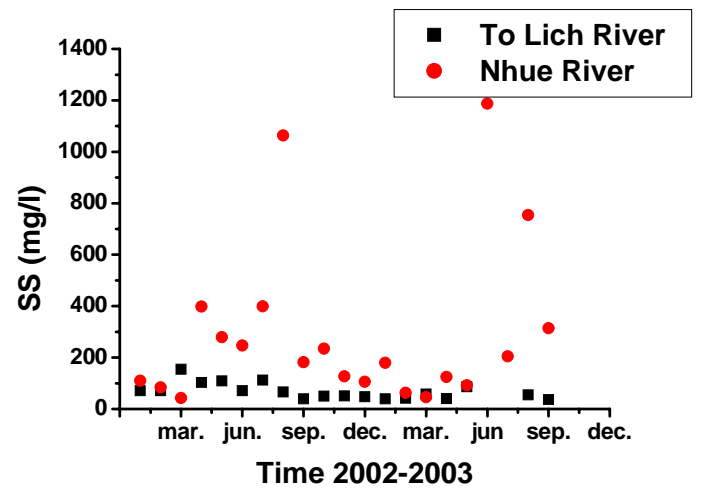

Fig. 2 Suspended solid downstream To Lich River, and upstream Nhue River monthly 2002 and 2003

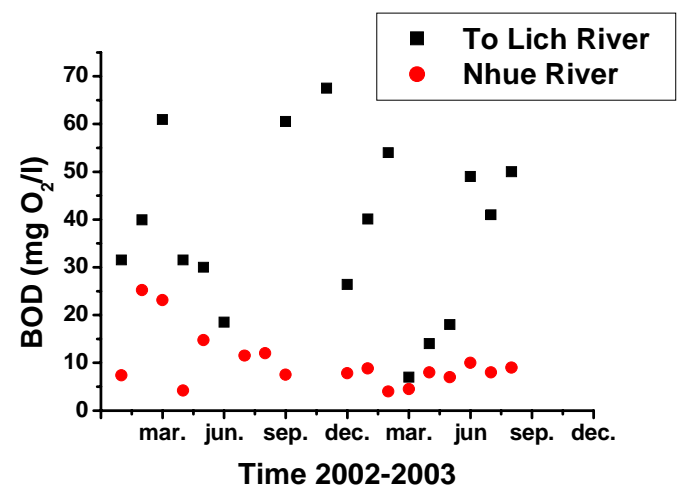

Fig. 3 BOD downstream To Lich River, and 5 km upstream the confluence in Nhue River monthly 2002 and 2003

where $h$ is local depth of flow, $u$ and $v$ are depthaverage velocity components in $\mathrm{x}$ and $\mathrm{y}$ directions, respectively, $g$ is gravitational acceleration, $\tau_{b}{ }^{x}$ and $\tau_{b}^{y}$ are bottom shear stresses, $\tau_{v}^{x}$ and $\tau_{v}^{y}$ are additional bottom shear stresses due to vegetation, $z_{s}$ is water height from reference level, and $\overline{u^{\prime 2}}, \overline{u^{\prime} v^{\prime}}$, and $\overline{v^{\prime 2}}$ are depth-average Reynolds stresses.

The governing equations for transport and conversion of state variables listed in Table $\mathbf{1}$ consist of the transport and conversion terms. The transport term including advection and dispersion is identical for every variable. The conversion term differs from variable to variable to characterize the bio-physicochemical processes that variables experience in aquatic media. Thus the mathematical expression of the temporal change of variable is:

$$
\begin{aligned}
& h \frac{\partial C_{i}}{\partial t}=-h\left(u \frac{\partial C_{i}}{\partial x}+v \frac{\partial C_{i}}{\partial y}\right) \\
& +h\left[\frac{\partial}{\partial x}\left(\varepsilon_{\text {sh }} \frac{\partial C_{i}}{\partial x}\right)+\frac{\partial}{\partial y}\left(\varepsilon_{\text {sh }} \frac{\partial C_{i}}{\partial y}\right)\right]+\text { Conver. }\left(C_{i}\right)
\end{aligned}
$$

in which $C_{i}$ indicates concentration of considered state variable, $\varepsilon_{s h}$ is lateral diffusivity and assumed equal to horizontal eddy viscosity, and Conver. $\left(C_{i}\right)$ represents the conversion term of variable (Table 2). 
Table 1 Model state variables

\begin{tabular}{|l|l|l|}
\hline Variable & Symbol & Unit \\
\hline \hline Inorganic suspended solid & $\mathrm{SS}$ & $\mathrm{mg} \mathrm{SS} / \mathrm{l}$ \\
\hline Dissolved oxygen & $\mathrm{DO}$ & $\mathrm{mg} \mathrm{O}_{2} / \mathrm{l}$ \\
\hline Biological oxygen demand & $\mathrm{BOD}$ & $\mathrm{mg} \mathrm{O}_{2} / \mathrm{l}$ \\
\hline Ammonia nitrogen & $\mathrm{NH}_{4}$ & $\mathrm{mg} \mathrm{N} / \mathrm{l}$ \\
\hline Nitrate nitrogen & $\mathrm{NO}_{3}$ & $\mathrm{mg} \mathrm{N} / \mathrm{l}$ \\
\hline Phytoplankton & $\mathrm{CHL}$ & $\mathrm{mg} \mathrm{C} / \mathrm{l}$ \\
\hline Total dissolved inorganic carbon & $\mathrm{C}_{\mathrm{T}}$ & $\mathrm{mg} \mathrm{C} / \mathrm{l}$ \\
\hline Alkalinity & $\mathrm{ALK}$ & $\mathrm{mmol} \mathrm{H} / \mathrm{l}$ \\
\hline pH/H ${ }^{+}$ & {$\left[\mathrm{H}^{+}\right]$} & $\mathrm{mg} \mathrm{H} / \mathrm{l}$ \\
\hline
\end{tabular}

Table 2 Bio-physicochemical processes present in conversion terms of variables

\begin{tabular}{|c|c|}
\hline Variable & Conversion term \\
\hline SS & $E r-D e$ \\
\hline BOD & $\begin{array}{l}\text { Hyd }+ \text { FastCOxid }-R_{O_{\text {Deniri }}} \text { Denitri } \\
+ \text { Sed }_{B O D}-\text { Sett }_{B O D}\end{array}$ \\
\hline CHL & Growth $_{\mathrm{CHL}}-$ Death $_{\mathrm{CHL}}-\operatorname{Resp}_{\mathrm{CHL}}-$ Settl $_{\mathrm{CHL}}$ \\
\hline DO & $\begin{array}{l}R_{O C_{C H L}} \text { Growth }_{C H L}-R_{O_{C H L}} \text { Death }_{C H L}-S O D \\
- \text { FastCOxid }-R_{\text {ON NTRL }_{\text {NRI }}} \text { Nitri + Re aeO }\end{array}$ \\
\hline $\mathrm{NH}_{4}$ & $\begin{array}{l}R_{N O_{H y d}} H y d-R_{N C_{C H L}} P_{a p} \text { Growth }_{C H L} \\
+R_{N C_{C H L}} \text { Re } s p_{C H L}-N i t r i+\text { Sed }_{N_{4}} \\
\end{array}$ \\
\hline $\mathrm{NO}_{3}$ & $\begin{array}{l}\text { Nitri - Denitri } \\
-R_{\mathrm{NO}_{3} \mathrm{C}_{\mathrm{CHL}}}\left(1-P_{\text {ap }}\right) \text { Growth }_{\mathrm{CHL}}-\mathrm{Sed}_{\mathrm{NO}_{3}}\end{array}$ \\
\hline $\mathrm{C}_{\mathrm{T}}$ & 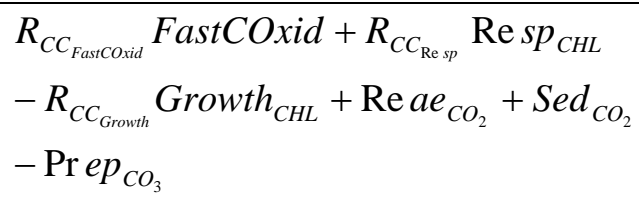 \\
\hline ALK & $\begin{array}{l}R_{A L K, C H L} \operatorname{Re} s p_{C H L}-\left(R_{A L K, C H L} P_{a p}\right. \\
\left.-R_{A L K, N}\left(1-P_{a p}\right)\right) G r o w t h_{C H L} \\
-R_{A L K, \text { Nitr }} \text { Nitri }+R_{A L K, \text { Deni }} \text { Denitri }\end{array}$ \\
\hline $\mathrm{pH} /\left[\mathrm{H}^{+}\right]$ & $f\left(\left\lfloor H^{+}\right\rfloor\right)$ \\
\hline
\end{tabular}

Detail description of processes and their parameters is given by Chapra et $\mathrm{al}^{1)}$ and Trinh et $\mathrm{al}^{5 \text { ) }}$

\section{SIMULATION AND DISCUSSION}

Previously, a 1-D numerical model was applied for calculation of longitudinal variation of water quality to the whole Nhue River ${ }^{5)}$. However, attempts in calculation precisely water state around the confluence, such as back water effect in To Lich River or lateral stratification of water quality after mixing of two water masses was unsatisfactory because of limits of 1-D model. Thus, 2-D approach was expected to resolve those tasks. Moreover, bed deformation and flooding calculations, the ultimate calculations should be taken into account in such high suspended load and easily flooding river, could be further made with the 2-D model.

\section{(1) Backwater and lateral stratification}

In term of hydrodynamic simulation, a two upstream inflow system was set up. It should be mentioned that in this river system whenever discharge in the Nhue increased (water level increased as well), Thanh Liet dam was partly or completely close to prevent backwater to Hanoi city (Fig. 1). Therefore, the common tendency is that discharge of the To Lich River decreased when discharge of the Nhue increased. Based on these observations, a one day hydrodynamic boundary conditions was set up.

As mentioned early, the environmental data that we have were applied for large scale area and no data were collected exactly at the same positions of boundaries of the selected area for this 2-D model. Thus, the data collected at nearest positions of this studied site were applied for simulation. It was expected that this application would provide typical environmental change of the studied river (Table 3).

\section{a) Transport of suspended sediment}

As introduced above, SS in the studied system consists of very different types: the alluvial inorganic SS and particulate organic detritus. These two SS types have different settling rates and when two water masses mixed together after the confluence, they tended to flocculate to form larger size particles. However, due to data deficiency, only one settling rate was selected for calculation. A value of $3.9 \mathrm{~m} / \mathrm{d}$ was extracted from the work of Trinh et $\mathrm{al}^{5)}$ and applied for this model as settling rate of inorganic SS. The particulate organic detritus was formulated as a part of BOD. The simulated transport of inorganic SS at different discharge conditions is shown in Fig. 4.

As seen from Fig. 4, inorganic SS abundant in mainstream intruded into To Lich River when the Thanh Liet dam was close. In this simulation, after 3.8 hours, discharge in To Lich River was zero and the inorganic SS intruded more than $200 \mathrm{~m}$ into the To Lich at 4.21 hours (Fig. 4b). 
Table 3 Boundary conditions; taken averagely from the 20022003 monthly samplings at $5 \mathrm{~km}$ upstream the confluence in Nhue River (mainstream) and at $800 \mathrm{~m}$ upstream the confluence in To Lich River (tributary)

\begin{tabular}{|l|c|c|}
\hline Variable & Mainstream & Tributary \\
\hline \hline $\mathrm{SS}(\mathrm{mg} / \mathrm{l})$ & 72.00 & 3.00 \\
\hline $\mathrm{DO}(\mathrm{mg} / \mathrm{l})$ & 6.00 & 1.00 \\
\hline $\mathrm{BOD}(\mathrm{mg} \mathrm{C} / \mathrm{l})$ & 11.80 & 58.70 \\
\hline $\mathrm{NO}_{3}(\mathrm{mg} \mathrm{N} / \mathrm{l})$ & 0.53 & 0.31 \\
\hline $\mathrm{NH}_{4}(\mathrm{mg} \mathrm{N} / \mathrm{l})$ & 0.65 & 12.62 \\
\hline $\mathrm{CHL}(\mathrm{mg} \mathrm{C} / \mathrm{l})$ & 0.319 & 0.781 \\
\hline $\mathrm{pH}$ & 7.39 & 7.46 \\
\hline
\end{tabular}

Alkalinity and $\mathrm{C}_{\mathrm{T}}$ were calculated from equilibria between $\mathrm{H}^{+}$and other major ions in water

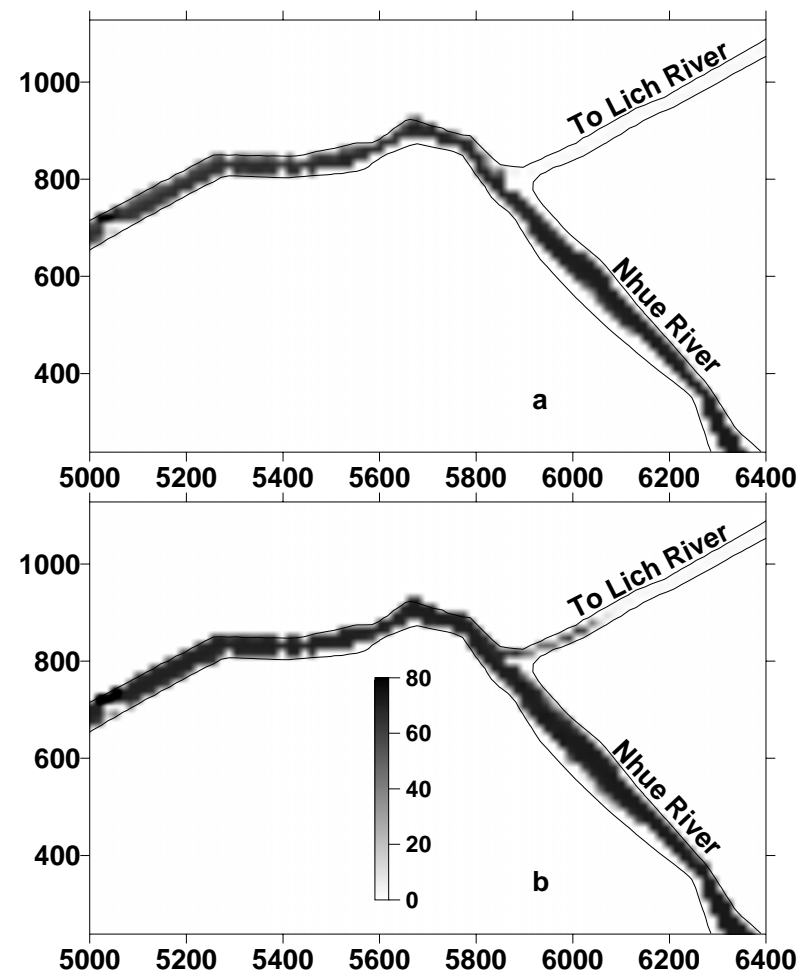

Fig. 4 Visualization the inorganic SS at different discharges; mainstream and tributary inflows in (a) $=27.8 \mathrm{~m}^{3} / \mathrm{s}$ and 1.8 $\mathrm{m}^{3} / \mathrm{s}$, respectively, in (b) $=44.6 \mathrm{~m}^{3} / \mathrm{s}$ and 0.005 , respectively

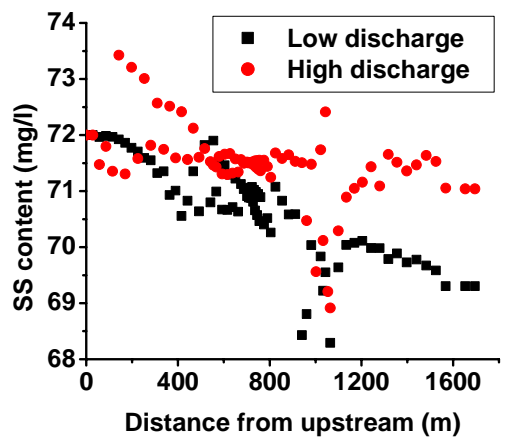

Fig. 5 Longitudinal SS profiles at the stream center in low (35 $\left.\mathrm{m}^{3} / \mathrm{s}\right)$ and high $\left(82 \mathrm{~m}^{3} / \mathrm{s}\right)$ discharges
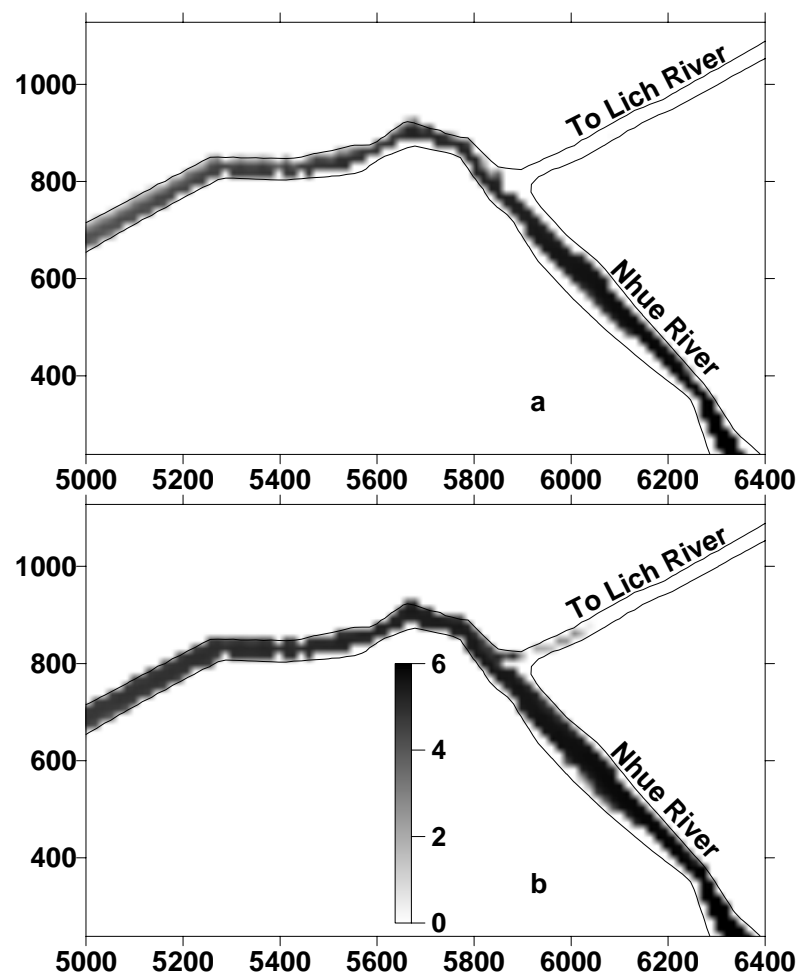

Fig. 6 Transport of dissolved oxygen (mainstream inflow and tributary inflow in [a] $=27.8 \mathrm{~m}^{3} / \mathrm{s}$ and $1.8 \mathrm{~m}^{3} / \mathrm{s}$, respectively; in [b] $=44.6 \mathrm{~m}^{3} / \mathrm{s}$ and $0.005 \mathrm{~m}^{3} / \mathrm{s}$, respectively)

Since settling rate applied for this simulation was calibrated from monthly data throughout 2 consecutive years 2002-2003 usually showed gradual decrease of SS content downstream, it was expected that the simulation would show similar result.

In order to examine this expectation, longitudinal variations of SS at different discharge conditions were taken into account (Fig. 5). Clearly, the applied settling rate produced deposition, even at extremely high discharge (SS content reduced downstream). Thus it is concluded that this 2-D model applied for SS simulation is rational.

\section{b) Variation of nutrients}

The simulation of nutrients and biological organism transport and conversion is centerpiece of ecological modeling. The success of ecological model application relies on this simulation.

Fig. 6 represents the profiles of simulated DO at different discharges. In all profiles, especially Fig. 6a when the To Lich River's discharge was significant the simulated DO decreased downstream. This decreasing tendency is seen at every discharge level, since downstream DO was always lower than upstream boundary (Fig. 8). That was similar to the fieldwork since benthic activity was strong and the DO hardly rose up to be equal its upstream level.

Other notice from the simulation of DO is that when discharge of the To Lich was insignificant 
(Fig. 6b), DO level in the To Lich River, close to the confluence, was also raised. It is similar to the simulation of SS and field observation (results not shown). This notice was applied not only for DO and SS but also for other variables. To make it clear, the computations of phytoplankton and $\mathrm{NH}_{4}$ at 100 $m$ upstream the confluence in the To Lich River are shown in Fig. 7. As expected, when Thanh Liet dam was close in high discharge, water from Nhue River had flown in and changed water quality there. So, at high discharge of the Nhue, one can find water in To Lich River as fresh as in Nhue River.

\section{c) Lateral stratification}

One question could be answered in application of 2-D depth average model is how water changes laterally. In application to the confluence between Nhue and To Lich Rivers, this question becomes strategic since downstream water is result from mixing of two different water masses. In some field observations water quality was seen laterally stratified few hundreds meter downstream the confluence. Sediment samples collected in two river banks about $100 \mathrm{~m}$ downstream the confluence contained different amount of particulate organic matters (sediment in left bank where To Lich River joins Nhue River had higher organic matter content than sediment in the right bank had (results not shown)). The 2-D depth average model could help to identify the spatial and temporal scale of this stratification.

Apparently, the simulated river reach was not sufficiently long enough to observe a complete mixing of two water masses (Fig. 8). At 2.92 hours and 24 hours when the To Lich's inflow was set as 1.8 and $3.2 \mathrm{~m}^{3} / \mathrm{s}$, respectively, the DO level downstream the simulation area was significantly different from left bank to right bank. So when the To Lich's inflow was substantial, one could observe a lateral stratification about $800 \mathrm{~m}$ downstream the confluence. However, it should be noted that water transport in this model was purely governed by hydraulic force and rather simple hydrodynamic resistance. The calculation did not take into account human activities (mussel harvesting, duck culturing, boating) or complexity of the river bed where submerged artificial objects and tree-type vegetation have sometimes altered the regularity of hydraulic flow.

\section{(2) Diurnal variation of water quality in April 23-24 2003}

In previous subsection, the 2-D model was tested at different discharges to perceive typical change of water quality in extreme conditions. In this subsection the model was employed to simulate

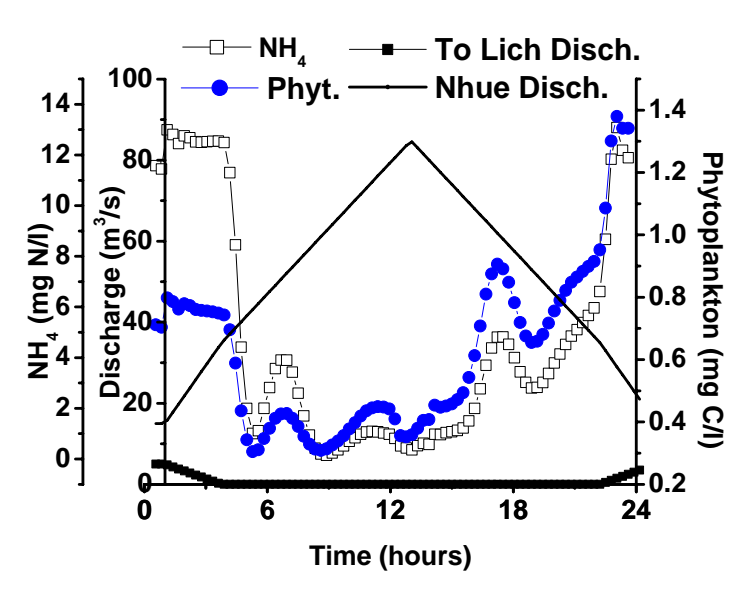

Fig. 7 Variations of water quality downstream To Lich River

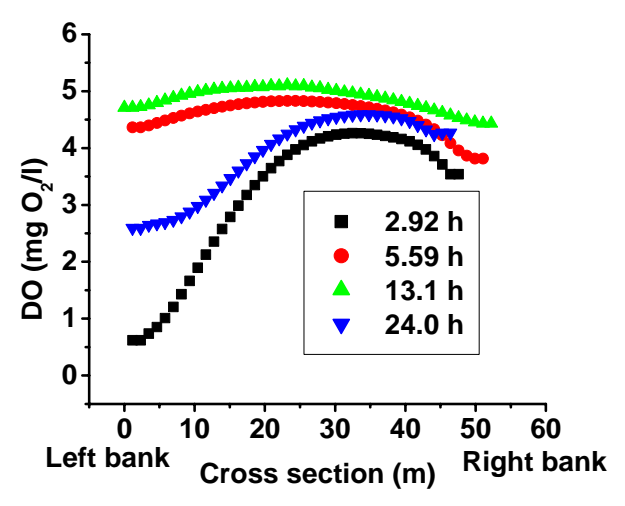

Fig. 8 Cross sectional profiles of downstream DO

the observation obtained in April 23-24 2003 when water quality varied considerably between day and night. It was observed that in April 23-24, downstream discharge was nearly constant at 20 $\mathrm{m}^{3} / \mathrm{s}$. Thanh Liet Dam was open to maintain a discharge of $5 \mathrm{~m}^{3} / \mathrm{s}^{5}$. Boundary conditions of state variables were taken as in Table 3 . The simulation results of $\mathrm{DO}$ and $\mathrm{NH}_{4}$ together with measured data collected at monitoring station $5 \mathrm{~km}$ downstream the confluence are shown in Fig. 9-10. Because the downstream of the simulated area was still $4 \mathrm{~km}$ upstream the monitoring station, we could only have a qualitative comparison of the measured and simulation results. The high BOD loading from To Lich River was main reason for very low DO at 5 km downstream the confluence (Fig. 9).

Although, the simulated DO level was not as low as the observation (around $3 \mathrm{mg} / \mathrm{l}$ ) but this level tended to decrease and could reach the same low level after $5 \mathrm{~km}$. The magnitude of simulated DO level change was about $0.15 \mathrm{mg} / \mathrm{l}$ and could be as high as $1 \mathrm{mg} / \mathrm{l}$ after $5 \mathrm{~km}$ to be similar with the observation (Fig. 9). Diurnal change of $\mathrm{NH}_{4}$ was observed though not so clear and coincident with our experiment data (Fig. 10). The small diurnal variation of $\mathrm{NH}_{4}$ indicated that $\mathrm{NH}_{4}$ in water was extensive to phytoplankton uptake. 


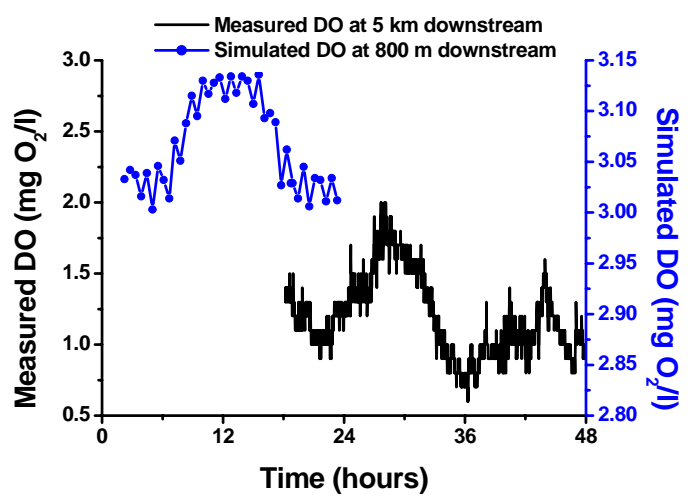

Fig. 9 Diurnal variation of DO downstream the confluence

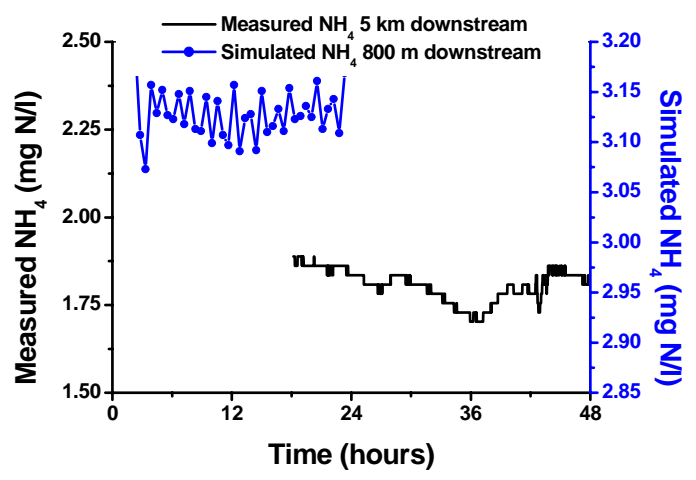

Fig. 10 Diurnal variation of $\mathrm{NH}_{4}$ downstream the confluence

\section{CONCLUSION}

It is the first time that a 2-D hydrodynamic+ biochemical model was successfully applied for the junction between Nhue River and To Lich River. The advantage of application of 2-D numerical model compared with 1-D model is that it could simulate smoothly transport of state variables at junction between river reaches. With 2-D model, one could simulate back water effect observed frequently in To Lich River when Nhue River's discharge was high. Simulation showed that within the calculation area and in low discharge condition, water was not completely mixed. Lateral stratification of different water quality still can be seen few hundred meters downstream. With more study on sediment contribution, vegetation coverage, SS flocculation and roughness coefficient, more precise simulation could be obtained.

In future, bed deformation due to high SS load and flooding can be simulated based on the current study. Based on this conceptual scheme, a more universal and complete biochemical model can be setup. The complete model can simulate separately biomasses of bacteria, zooplankton, dissolved organics and particulate organics.

ACKNOWLEDGMENT: The study was conducted under the frame of the UNESCO International Research Course for the Environment 2004-2005 at Tokyo Institute of Technology.

\section{REFERENCES}

1) Chapra, S.C. and Pelletier, G.J. QUAL2K: A Modeling Framework for Simulating River and Stream Water Quality: Documentation and Users Manual. Civil and environmental Engineering Dept., Tufts University, Medford, MA, 2003.

2) JICA The study on Urban Drainage and Wastewater Disposal System in Hanoi city, Final report, 1995.

3) Janssen-Stelder B.M, Augustinus P.G.E.F., and van Santen W.A.C.: Sedimentation in a coastal mangrove system, Red River delta, Vietnam. Fine Sediment Marine Dynamics in the Marine Environment. J.C. Winterwerp and C. Kranenburg (Editors) pp.455-567, 2002.

4) Brown, L.C., and Barnwell, T.O. The Enhanced Stream Water Quality Models QUAL2E and QUAL2E-UNCAS, EPA/600/3-87-007, U.S. Environmental Protection Agency, Athens, GA, pp.189, 1987.

5) Trinh A. D., Bonnet M. P., Vachaud G., Chau V. M., Prieur N., Vu D. L., Le L. A. : Biochemical modeling of the Nhue River (Hanoi, Vietnam); practical identifiability analysis and parameters estimation, Ecol. Mod., In press, 2005.

6) Ikeda S., Ohta K. and Hasegawa H. Effect of bank vegetation of flow and sediment deposition, Journal of Hydraulic, Coastal and Environmental Engineering, JSCE, Vol.447, pp.25-34, 1992. (in Japanese)

7) Ikeda S. and Izumi N. Effect of pile dikes on flow retardation and sediment transport, Journal of Hydraulic Engineering, ASCE, Vol.117(11), pp.1459-1478, 1991.

8) O'Connor D. J. and Dobbins W. E. Mechanisms of reaeration in natural streams, Trans. Am. Soc. Civ. Eng., Vol.123, pp.641-684, 1958.

9) Stumm W., Morgan J. J. Aquatic Chemistry: Chemical Equilibria and Rates in Natural Waters, Third ed. John Wiley \& Sons, Inc. 1996.

10) Reichert P., Borchardt D., Henze M., Rauch W., Shanahan P., Somlyódy L. and Vanrolleghem P.: River Water Quality Model no. 1 (RWQM1): II. Biochemical process equations, Wat. Sci. Tech., Vol.43(5), pp.11-30, 2001.

11) Brion N. and Billen G.: Wastewater as a source of nitrifying bacteria in river systems: the case of the river Seine downstream from Paris, Wat. Res. Vol.34(12), pp. 3213-3221, 2000.

12) Henze M., Grady C.P.L., Gujer W., Marais G.v.R. and Matsuo T.: Activated sludge model No. 1. IAWQ, London, ISSN, 1010-707X, 1987.

(Received September 30, 2005) 